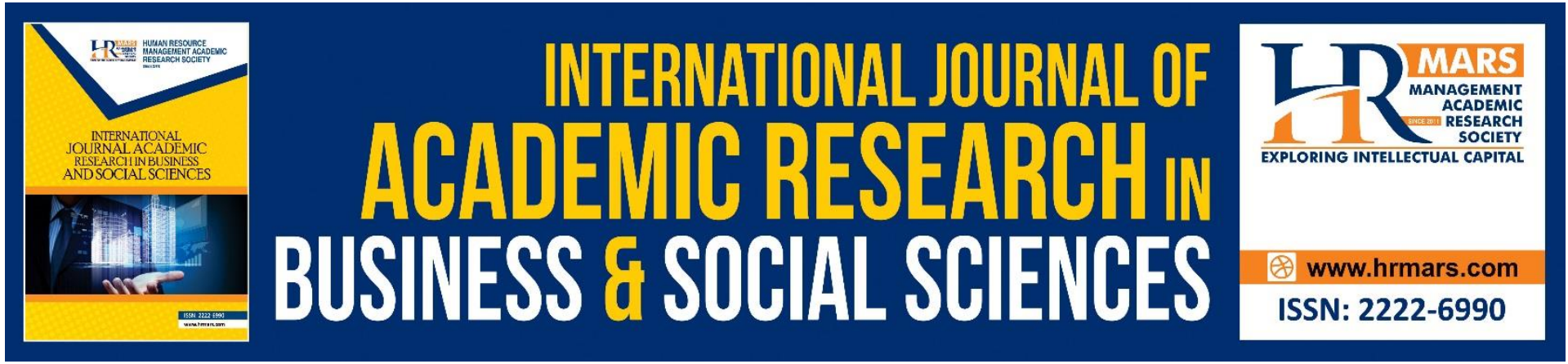

\title{
The Usage Patterns of Social Media among University Students in Malaysia During the Movement Control Order (MCO)
}

Muhammad Husairi Kamisan, Mohd Syuhaidi Abu Bakar

To Link this Article: http://dx.doi.org/10.6007/IJARBSS/v11-i9/10971

DOI:10.6007/IJARBSS/v11-i9/10971

Received: 09 July 2021, Revised: 02 August 2021, Accepted: 23 August 2021

Published Online: 08 September 2021

In-Text Citation: (Kamisan \& Bakar, 2021)

To Cite this Article: Kamisan, M. H., \& Bakar, M. S. A. (2021). The Usage Patterns of Social Media among University Students in Malaysia During the Movement Control Order (MCO). International Journal of Academic Research in Business and Social Sciences, 11(9), 35-48.

Copyright: (c) 2021 The Author(s)

Published by Human Resource Management Academic Research Society (www.hrmars.com)

This article is published under the Creative Commons Attribution (CC BY 4.0) license. Anyone may reproduce, distribute, translate and create derivative works of this article (for both commercial and non-commercial purposes), subject to full attribution to the original publication and authors. The full terms of this license may be seen

at: http://creativecommons.org/licences/by/4.0/legalcode

Vol. 11, No. 9, 2021, Pg. 35 - 48

Full Terms \& Conditions of access and use can be found at http://hrmars.com/index.php/pages/detail/publication-ethics 


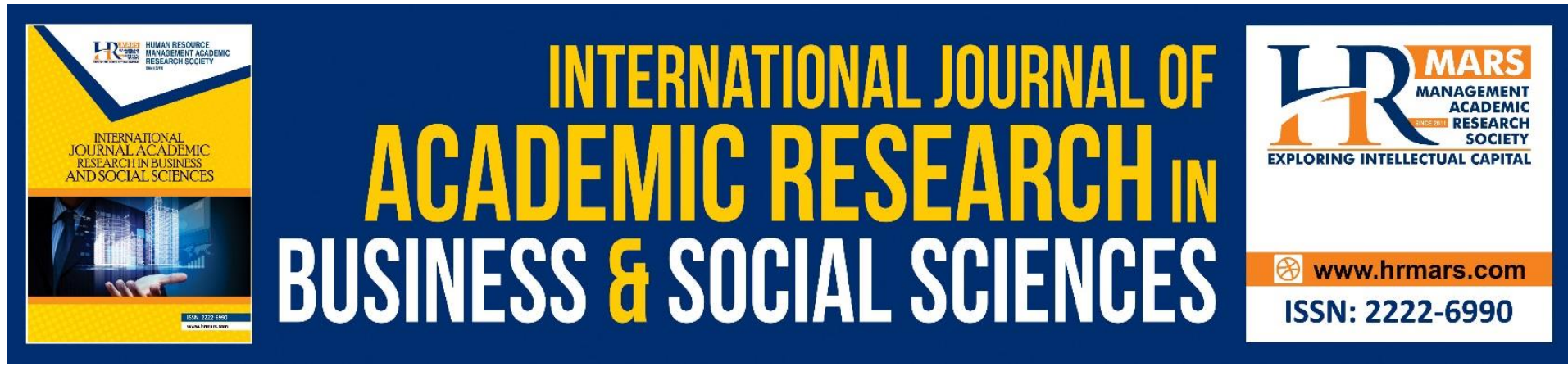

\title{
The Usage Patterns of Social Media among University Students in Malaysia During the Movement Control Order (MCO)
}

\author{
Muhammad Husairi Kamisan \\ Faculty of Film, Theatre, and Animation (FiTA) Universiti Teknologi MARA (UiTM), Puncak \\ Perdana Campus, Malaysia \\ Email: husairikamisan@gmail.com

\section{Mohd Syuhaidi Abu Bakar} \\ Faculty of Film, Theatre, and Animation (FiTA) Universiti Teknologi MARA (UiTM), Puncak \\ Perdana Campus, Malaysia \\ Email: syuhaidi@uitm.edu.my
}

\begin{abstract}
In the implementation of the Movement Control Order (MCO) throughout the country by the government of Malaysia on 18 March 2020, social media usage patterns have increased mainly among university students, as they have to resort to online learning. This paper studies the social media usage patterns among university students in order to investigate patterns of use from the point of view of content, duration of social media usage, and so on. This study uses structured interviews in data collection and 12 informants have been interviewed. Data were transcribed verbatim. The results show that university students use social media as a medium of communication, a platform for information dissemination, a source of information, a platform for learning and sharing of knowledge, and as a platform for support and assistance. Most informants are considered to have made full use of social networks throughout the MCO, especially for learning and communication purposes.
\end{abstract}

Keywords: Usage Patterns, Social Media, University Students, Malaysia, Movement Control Order, MCO, COVID-19

\section{Introduction}

Social media plays an important role in communicating the latest information to students. It allows the exchange of academic materials between students and lecturers for the purpose of learning as well as assisting students to complete their assignments. The significant role of social media is further amplified during the Movement Control Order (MCO) period as it serves as a useful medium for students to communicate with their families, obtain the latest news related to the current situation, entertainment, as well as education and academic matters. Subsequently, this creates the new norm of online learning particularly among university students (Afandi, 2020). 
Norazman, Kumar and Basiron (2019) explain that social media is a necessity that encompasses the daily lives of human beings. In general, social media refers to websites that serve as an online forum, platform, or space for social interaction and socialisation to happen between communities around the world. It includes various types of internet-based communication such as emails, websites, blogs, social media, social networks, and even chat or online chatting apps. Among the reason why social media forms a daily usage among university students is the enormous amount of time that they spend at home. Previously, their daily 24 hours were spent on working or completing academic-related chores during the day followed by a few hours of rest and sleep at night. Nevertheless, such schedule has been altered following the MCO where almost all Malaysians including university students were required to stay indoors.

Bernama (2020) reports that on 16 March 2020, the former Prime Minister of Malaysia, Tan Sri Dato' Hj. Muhyiddin bin $\mathrm{Hj}$. Mohd. Yassin had declared the MCO enforcement across the nation from 18 March 2020 to 31 March 2020 as part of the effort to curb and control the COVID-19 from spreading and causing more casualties. Consequently, such enforcement had placed significant limitation on the daily movement of all Malaysians and a complete ban on any mass gatherings including religious activities, cultural activities, social activities and sports activities. In addition, authorities such as The Royal Malaysian Police (RMP) and Malaysian Armed Force (MAF) were empowered to control the movement of people across Malaysia in ensuring their compliance with the MCO.

Mutalib (2020) explains that following the former Prime Minister's announcement on the implementation of the MCO, the majority of Malaysians began to make panic buying particularly on food supplies which subsequently disrupted the supply chain of rations at most business premises particularly when the delivery of supplies was delayed due to the travelling limitation. Such excessive purchases not only caused food wastage but also posed unnecessary difficulty for the poor and the needy to obtain supplies. Furthermore, the panic buying situation also increased the risk of spreading the COVID-19 virus due to the mass gathering of shoppers at supermarkets and business premises. On 25 March 25 2020, the former Prime Minister, Tan Sri Muhyiddin Yassin had announced on the extension of the MCO period from 1 April to 14 April 2020 following the increased number of infections and deaths cases in Malaysia. In the Second Phase, the government had implemented additional law where petrol stations and business premises that sell daily essential goods were permitted to operate from $8 \mathrm{am}$ to $8 \mathrm{pm}$ daily. Movement of the public was also restricted within 10 kilometres radius from their respective houses and starting from 8 April 2020, The Royal Malaysian Police (RMP) was empowered to charge a RM1,000 fine to individuals who disobeyed the MCO.

Idris, Ibrahim and Arifin (2020) reports that on 10 April 2020, the former Prime Minister had announced the Third Phase MCO extension from 15 April 2020 to 28 April 2020. During this phase, the academic session for all schools and higher education institutions across Malaysia was postponed to a later date that will be announced. The government also closed its borders from receiving external visitors to reduce the spread of the COVID-19 virus.

This was followed by the Fourth Phase of MCO, implemented from 29 April 2020 to 12 May 2020 which was later changed to the Conditional Movement Control Order (CMCO) from 4 
May 2020 onwards following the decline in the number of local COVID-19 cases. During this phase, the former Senior Minister (Security Cluster), Datuk Seri Ismail Sabri Yaakob agreed to retract the 10 kilometres radius movement restriction (Roslan and Aling, 2020).

This paper focuses on the usage patterns of social media among university students in Malaysia during the MCO period. The MCO period is still ongoing in 2021 for Malaysia.

This study will contribute to the academic aspect and contribute to the pool of knowledge and future references related to the use of social media among students during the MCO period by raising the question on what is the patterns of social media usage by university students in Malaysia.

\section{Literature Review}

The internet is part of the daily necessities for all walks of life. It allows the public to connect with one another as evident by the increase usage of social media. This is further amplified by the ease to access the internet via smartphones as it provides instant access to information and bridges the connections with one another (Ariffin, 2020).

According to Fauzi (2017), the use of social media should first be viewed from a negative standpoint where the main challenge is to ensure the authenticity and accuracy of information that are obtained and disseminated through social media. With the current technological advancement, the society is exposed to fake news and false information that are then passed to other people without any control and possess devastating effects to the receivers. The federal government takes this issue seriously and the ongoing initiative by the Malaysian Communications and Multimedia Commission (MCMC) to curb the spread of fake news and false information on social media is part of the federal government's effort to resolve the issue of fake news circulation by the public.

Moktar, Sherryna and Jasmi (2019) suggest that social media has contributed to the way educators teach their students. Aside from making teaching and learning to be less textbooks oriented, social media also has the potential to be utilised as a tool to conduct the teaching and learning activities as it contains animations, audios, and videos that are able to attract the students' interest and set a conducive and relaxed environment that facilitates the process of knowledge gaining and acquisition. Furthermore, learning through social media shall increase the efficacy of education to disseminate knowledge and information for the benefits of the students as well as the collective community.

Moreover, Azizan, Kariya and Jasmi (2019) state that the current millennium has seen the emergence of various technologies such as the social media and entertainment technology. These technologies have the capability to control human lives depending on its usage as well as how they are utilised. The existence of laws to protect the human rights also changes the system in most countries in accordance to the rules of various religions around the world.

According to Azmi, Kamalanathan and Jimaain (2019), the public believe on the importance to follow things like viral videos, up-to-date fashions, cooking recipes, and the sharing of one's personal story in order to keep up with the latest trend. Nevertheless, everything that appears on social media often possess both positive and negative influences. From the latter 
perspective, several cases of obscenity, offensive, and inappropriate subjects have been reported against the contents that are available on social media. Besides that, viral videos on social media have now been made as a daily source of entertainment by the public despite its possibility of having negative impacts to the society as well as the spread of fake news and gossiping about the household affairs of others that often appear to be shamelessly distributed on social media platforms such as Facebook and Twitter. On the other hand, social media is also used to facilitate the implementation of e-learning by educators, lecturers, and students at every higher education institution in Malaysia. E-learning allows students to access their learning notes at their convenient in order for them to review the lessons anytime and anywhere.

According to Ariffin (2020), today's technology enables the quick obtainment of information via internet through the use of smartphones or computers. The obtained information such as the official reporting of the pandemic outbreak as well as the latest news and information are also more transparent and can be widely disseminated through various channels including the official social media accounts of the ministries in Malaysia. The technological advancement has also changed the pace of education development in Malaysia as well as worldwide. In this regard, social media has shifted the education paradigm from being textbooks oriented to become digital learning. Apart from easing the accessible of reading materials through the use of certain educational applications that are shared directly with the recipients, social media also contains animations, videos, audios, and sketches that are able to enhance the learning motivation of pre-schoolers, secondary school students, as well as those at higher learning institutions. This increases their focus during the MCO period hence making learning more flexible and relax. Furthermore, social media also helps to convey information and obtain learning materials through the use of internet. There are several applications utilised by educators as well as students in delivering and receiving online academic materials and information via social media.

\section{Social Media Platforms in Malaysia Facebook}

Aziz (2015) explains that the public acceptance of Facebook has made it as among the popular social networking sites among the Internet users as a medium to express their ideas, opinions, and everyday life activities. The use of Facebook is also extended at workplaces as one of the platforms used by staff to communicate with the top managers although such practice indirectly creates unnecessary bureaucratic procedures. Generally, Facebook is an app that serves the purpose of finding new friends, communicating with the existing circle, as well as sharing the latest news, stories, and everyday activities. Nevertheless, the use of Facebook has recently been extended as a platform for business and marketing. Despite these benefits, several irresponsible parties have abused the use of Facebook to spread fake news as well as slanderous and hate-ridden content. However, if people are to understand the benefits of using social media such as Facebook, it will certainly be beneficial in creating a more positive atmosphere.

\section{Twitter}

According to Zulkifli (2017), Twitter is another social media platform that allows its users to interact with one another via writing and other elements like pictures and videos. Twitter has become an online medium used by the public, including students, to exchange ideas and share 
the latest news, trends, and current issues. Generally, the average users of Twitter range between 40 years old and below as opposed to Facebook. Unlike other social media platforms, each post on Twitter is set within a limited number of words. Hence, users often resort to the use of threads to communicate a longer story while bearing in mind on the possible issue of misunderstanding and misinterpretation by the receivers. They also have the option to share links, pictures, and videos that are related to the content that they wish to convey. Similar to the case of Facebook, the validity of the contents and news shared on Twitter is still bounded to be checked and validated by the receivers. However, Twitter users can still obtain authentic and accurate information from the official Twitter accounts of the ministries in Malaysia such as the Ministry of Education Malaysia and the Ministry of Health Malaysia.

\section{Instagram}

Sharudin, Mustaffa and Sannusi (2020) explain that Instagram is a social media platform that facilitates the communication between its users via visual messages. In this regard, each content posted by the users shall depends on the types of visual used where posts that carry positive elements tend to be openly perceived by the public as opposed to those that contain negative vibes such as posts that contain insults, curses, and downgrading others. From the local perspective, the young generation in Malaysia is prone towards using Instagram due to its simplicity that eases the process of perceiving, understanding, and sharing the visual elements. In the early days of Instagram, users solely perceived its concept for the purpose of sharing pictures that depicted their memories, life, flora and fauna, as well as sceneries. However, the function of Instagram has expanded over time where the social media platform has become a popular medium to deliver messages, news, and entertainment content. Nevertheless, the home screen to the users' profile still adheres to the visuals that they have created. For instance, an entertainment page on Instagram that contains beautiful and aesthetic visuals has more significant chances to attract more viewers and visitors. Furthermore, Instagram can also be integrated with Facebook's messenger application. Such function not only facilitates online business activities but also enables the ministries in Malaysia to integrate and simultaneously manage their official social media accounts for the public to obtain the latest, authentic, and reliable news.

\section{WhatsApp}

In the context of e-learning, Zakaria and Abdullah (2018) describe WhatsApp as an important communication platform between the educators and lecturers with the students. It offers various facilities and advantages such as text messages, audios, videos, images, voice and audio calls, links to websites, and file sharing that mutually benefit the users. In addition, the majority of Malaysian students tend to use their native language rather than English even during the English class. During the MCO, WhatsApp is one of the commonly used applications by the public to communicate with one another. Most of the news shared through WhatsApp may of unknown validity and authenticity and the practice of "copying and pasting" or "forwarding" such news is still rampant among the users. WhatsApp uses the phone number of the users as the basis for its internet-based chat and it is widely utilised as a medium of communication that connects friends and families. 


\section{Methodology}

According to Jasmi (2012), qualitative research needs to understand something in-depth and close enough to the person or situation to be studied to facilitate a comprehensive study. This qualitative study interviewed twelve (12) students aged between 20 and 27 who are enrolled in public higher learning institutions across Malaysia. A total of eight questions were asked to the informants about their patterns of social media usage during the MCO period. The interview questions focused on the role of social media as a medium of communication, social media as a platform for information dissemination, social media as a source of information, social media for the learning and sharing of knowledge, and social media as a platform for support and assistance. Data were transcribed verbatim.

\section{Findings and Discussion}

\section{Social Media as a Medium of Communication}

Social media plays a major role amongst university students during the MCO period as a platform for them to express their thoughts and emotions as well as to quickly share and obtain authentic information. It also helps the informants to obtain accurate information related to the $\mathrm{MCO}$ as well as academic matters.

All 12 informants agree on the prominent role of social media as the medium for communication during the MCO. As stated by Informant 1, social media allows students to share the latest information and current issues as well as communicating with the lecturers in order to complete the assignments, particularly those that were assigned before the MCO enforcement. Informant 7 further adds that social media is the sole medium available for students to communicate with their lecturers and friends despite having limited Internet speed.

\section{WhatsApp}

WhatsApp is the most commonly used social media application by university students to keep track with the learning process during the MCO. Lecturers and students interacted via WhatsApp groups on daily basis to ensure that all academic matters were successfully conducted in a timely manner for the benefit of the students. WhatsApp is also seen as an easy-to-use application that only requires the users' personal phone numbers. It also allows the exchange of files and videos aside from the ability to make conference video calls.

According to Informant 4, learning is made easier through WhatsApp as students and lecturers can exchange educational information quicker. Informant 6 said, WhatsApp informs with the latest information about COVID-19 via shared links and the 'trending' feature on social media related to COVID-19 has kept people alert. Meanwhile, Informant 11 said WhatsApp was used as the medium to interact and communicate with the supervisor and lecturers during the MCO.

\section{Facebook}

Facebook is a social media application that connects its users worldwide. It allows users to upload and share photos and videos on their respective pages for the purpose of storage or public viewing among close friends during the MCO period. Aside from being a social media that promotes open sharing to mass audience, Facebook also allows its users to connect in personal through the Messenger application. Users are required to have an email to register 
for their personal Facebook account without the need to provide their personal phone number. In addition, Facebook also allows everyone to be friends following mutual agreement from both parties. Informant 4 said the society today is exposed to the use of gadgets, technologies, and the Internet for communication purpose especially through social media like Facebook.

\section{Instagram}

Instagram is a social media application that showcases pictures and videos as its main contents together with the captions written by the users. It is one of the commonly used application among university students during the MCO period in order to receive and convey contents related to the current issues as well as their daily activities. According to Informant 8 , the government and relevant agencies utilise the social media like Instagram as a medium to disseminate information. Users need to use social media wisely by only following valid and verified accounts so that they will only receive accurate and reliable information.

\section{Twitter}

Twitter is a social media application that focuses on the use of concise sentences and limited number of words to convey messages clearly. Most university students use Twitter to share links from blogs and websites for the purpose of sharing information.

Informant 5 use Twitter as there are numerous information shared by the official Twitter accounts of the Ministry of Health and the Ministry of Higher Education Malaysia, which make it so much easier for students. Informant 7 obtain information related to the COVID-19 pandemic from Twitter aside from having telephone conversations with family and friends.

\section{Social Media as a Platform for Information Dissemination}

There are several different perspectives on the use of social media by university students to find information about the COVID-19 outbreak. Informant 1 explains that social media enables students to obtain information about COVID-19 through reliable sources from the official social media account of the Ministry of Health Malaysia. Meanwhile, Informant 4 stresses on having better confidence to the news obtained from reliable websites such as the official Facebook, Twitter, and Instagram of the Ministry of Health Malaysia as well as the National Security Council (MKN). This is in contrast to Informant 7 who obtained information related to the COVID-19 pandemic through Twitter, the MySejahtera application, as well as from the phone calls with her family and friends. Similar to other students, Informant 7 admits of sharing the latest information and her daily activities on her WhatsApp status and Instagram Stories.

Besides that, 11 out of 12 informants agree that social media is the main medium to disseminate information related to COVID-19 and the MCO. Informant 2 admits that social media is a major source of COVID-19 news during the MCO period as the technological advancement has placed these information on our fingertips through Twitter accounts of Astro Awani and the Ministry of Health Malaysia. This is supported by Informant 3 who posits that social media applications are commonly installed and used by all smartphone users, hence facilitates them to obtain reliable information on COVID-19. Similar opinion is shared by Informant 4 and 6 who believe on the relevance of social media and Internet to their lives particularly for the purpose of obtaining information. However, Informant 12 insists that such 
information should only be released by the official social media accounts of relevant governmental agencies to prevent the spread of fake and inaccurate news.

Several informants disagree on the position of social media as the main medium to disseminate information related to COVID-19 as they prefer to receive such information from the live television update by the ministers themselves. However, these informants may still consider to obtain information from official mediums of the ministries but with caution as there are several fake accounts that resemble government agencies. Informant 8 disagrees on the prominence of social media as the main medium that delivers information about COVID-19 due to the large amount of false information being spread by irresponsible parties. Although he agrees that social media has the capability to quickly disseminate information, Informant 8 argues that careful attention and cautions must be invested by the public particularly on the validity and accuracy of the information. This further justifies inclination in making the daily televised coverage of government representatives as the most reliable source of information.

\section{Social Media as a Source of Information}

All Informants have stated their preference to receive information related to COVID-19 from the two sources, namely official social media accounts and their respective universities. Informant 10 explains that most of the information received by students came from their own search on the Ministry of Health website and by following official Telegram accounts. Despite admitting on the importance of both sources, Informant 3 believes that the information shared by the university is more reliable. Similarly, Informant 8 acknowledges that both sources of information are important but he highlights on the need to obtain news from legitimate sources. Furthermore, Informant 8 added that in this recent time, the dissemination of information related to the pandemic is important along with the necessity to check the validity of the news as false information is potentially harmful to others.

\section{Social Media as the Platform for Learning and Sharing of Knowledge}

University students have conducted learning activities through social media. Various initiatives are used by the students and universities to conduct learning activities with the assistance of several applications. Informant 4 admits of conducting discussions about her thesis with her supervisor via WhatsApp while Informant 5 communicated with her lecturers through video calls via Google Meet. Besides that, Informant 6 agrees that students seemed to be using social media applications to answer the questions posted by the lecturers as well to present their projects. Among the applications used are Facebook, Google Meet, Google Classroom, and Padlet. Informant 7 also agrees that the lecturers utilise a wide range of applications to provide assignments including WhatsApp, uFuture (used in Universiti Teknologi MARA), YouTube, Padlet, and Google Classroom. Meanwhile, Informant 8 explains that the applications commonly used by students are WhatsApp, Google Meet, Zoom, and Microsoft360 provided by the university. This is followed by Informant 9 who uses Telegram, Google Form, Microsoft Teams, Zoom, and Goals (Universiti Sains Islam Malaysia website) as well as Informant 11 who uses Google Classroom to complete all learning activities as well as Zoom and Skype applications to interact via live streaming with the supervisors, lecturers, and other students. 


\section{New Norms of Learning}

During the MCO period, most students have experienced a new learning system where online learning mediums such as Google Classroom, Google Meet, Zoom, and Skype are widely used following the limitation on any mass gathering, including conventional lectures and classroom learning. Informant 11 uses Google Classroom to complete all learning activities and also Zoom and Skype to interact via live streaming with lecturers and university friends. Informant 5 had learning activities conducted through video calls using Google Meet.

\section{Knowledge Sharing via WhatsApp}

Several students also use WhatsApp widely for teaching and learning activities with their supervisors. WhatsApp allows better communication between the students and supervisors and it also provides the option for file sharing at the convenient of their fingertips. This indicates that the local education sector has indirectly begun to utilise social media as a medium to deliver teaching and learning activities during the MCO. Informant 4 had held thesis discussions with her supervisor via WhatsApp.

\section{E-Learning}

The e-learning system is developed for the convenience of the educators and students in the education system particularly involving those at higher education institutions. Most universities have extensively utilised e-learning in its academic activities where it allows lectures and presentation of project papers to be conducted without the need for face-toface interactions.

Informant 6 used social media applications to answer questions posted by the lecturers and to present her project. The applications that were used such as Facebook, Google Meet, Google Classroom, and Padlet. Informant 9 used Telegram, Google Form, Microsoft Teams, Zoom, and Goals (Universiti Sains Islam Malaysia website), meanwhile Informant 8 connect with the learning activities through WhatsApp, Google Meet, Zoom, and Microsoft360 provided by the university. Informant 7 said lecturers provide assignments through a wide range of applications including WhatsApp, UFuture, YouTube, Padlet, and Google Classroom.

Mohamed (2011) explains that the e-learning system is developed to aid the efficiency of the teaching and learning process as well as the management and administration of the universities. Currently, it is used as a liaison between students and their lecturers to communicate and conduct online discussions, upload lecture notes, and convey information. Students also have the opportunity to answer a survey on the quality of teaching and lectures by the lecturers, download lecture notes, communicate knowledge and many other facilities depending on their institution. Today, a large number of education institutions from elementary schools to higher education institutions possess their own e-learning system for the convenience of all stakeholders. E-learning has also been introduced at urban and rural schools in line with the growth and development of e-learning in Malaysia. In addition, most schools in Malaysia also use e-learning as an initiative to bring education to the students from the comfort of their home. 


\section{Social Media as a Platform for Support and Assistance Social Media as Emotional Support}

Throughout the MCO period, it is evident that students in Malaysia are obedient to the orders given by the government to stay indoors within their residence, colleges, or dormitories in avoiding the risk of COVID-19 infection. The government also provide support and assistance in the form of donations to underprivileged students as well as offering words of encouragement to whom have to stay far from their families, in addition to the assistance received from the government. Informant 3 said students who are stranded are given comforting words from their friends via social media. They also obey the orders given by the government to curb the COVID-19 pandemic.

\section{Support for Stranded Students}

Stranded students are also provided with assistance from the universities and the Students Representative Council (SRC) in various forms including daily foods as the cafes and restaurants within the university ground are mostly closed. There are also students who volunteered to distribute food supplies to the stranded students as part of the effort to assist the Students Representative Council (SRC). Informant 7 said they were given foods every day for breakfast, lunch, and dinner based on data collected via online forms. During Ramadan, they also receive foods from the university for breakfast and sahur. Some of her friends also volunteered to distribute the food supplies in order to help the SRC.

\section{Financial Aid}

The government has also provided financial aid to students during the $\mathrm{MCO}$ as well as giving them with the opportunity to return to their hometowns by following specific and thorough procedures made by related agencies to curb the spread of the COVID-19 virus. Information on these aids was distributed online. The financial aid is given in response to the economic factors of the students and their families who may be having financial difficulties as a result of the MCO. Informant 12 said the university as well as the government provide financial assistance that ease the students' burden to buy and obtain learning needs such as Internet data. The government also assisted in the process of sending the university students back to their respective hometown.

Figure 1 below summarizes the usage patterns of social media among university students in Malaysia during the Movement Control Order (MCO). 


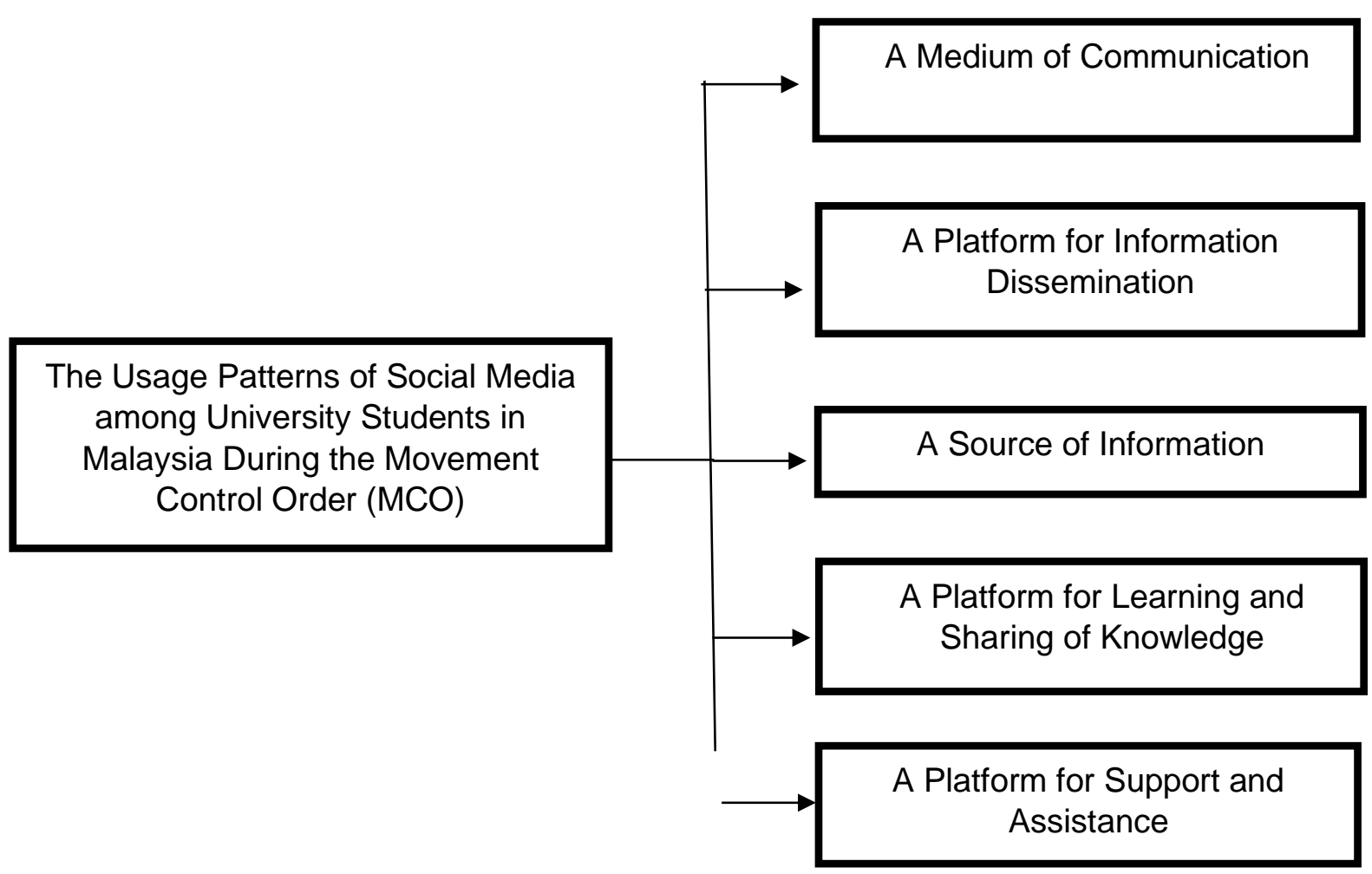

Figure 1: The Usage Patterns of Social Media among University Students in Malaysia During the Movement Control Order (MCO).

\section{Conclusion}

Highly interactive social media networks like Facebook, Instagram, Twitter, and WhatsApp besides apps such as MySejahtera have changed the way people communicate and obtain useful information. A study by Universiti Malaysia Terengganu (UMT) on social media and Islamic teaching methods has proven that social media is widely utilised today as a place for people to communicate and share information conveniently and quickly (Mutalib, Abd Halim and Yahaya, 2015).

The overall results of this study show that the use of technologies in teaching and learning has made a great difference in the field of education among students and educators. Changes in the field of education have created countries that are advance in the field of information technology as well as allowing educators to utilise internet via platforms such as e-learning, Facebook, Google Meet, Hangout, Skype, YouTube, and WhatsApp as the medium for teaching and learning activities. Such aspect shall benefit the stakeholders in the sharing and searching of knowledge. It can be concluded that public higher learning institutions students across Malaysia use social media as a medium of communication, a platform for information dissemination, a source of information, a platform for learning and sharing of knowledge, and as a platform for support and assistance.

\section{Corresponding Author}

Mohd Syuhaidi Abu Bakar

Faculty of Film, Theatre and Animation (FiTA) Universiti Teknologi MARA (UiTM), Shah Alam, Malaysia

Email: syuhaidi@uitm.edu.my 


\section{Acknowledgements}

The publication fee for this article is funded by the Faculty of Film, Theatre and Animation, Universiti Teknologi MARA (UiTM), Malaysia.

\section{References}

Afandi, A. (2020). Pengajaran, pembelajaran ketika pandemik bukan mudah. Retrieved from https://www.bharian.com.my/rencana/komentar/2020/12/769924/pengajaranpembelajaran-ketika-pandemik-bukan-mudah

Ariffin, A. (2020). Manfaatkan teknologi mudah alih sewaktu krisis COVID-19. Retrieved from https://www.astroawani.com/berita-malaysia/manfaatkan-teknologi-mudah-alihsewaktu-krisis-covid19-235798

Aziz, A. B. A. (2015). Penggunaan Facebook Page sebagai faktor perantara bagi perkaitan halangan komunikasi dengan pencapaian kerja dalam organisasi (Doctoral dissertation, Universiti Putra Malaysia). Retrieved from http://psasir.upm.edu.my/id/eprint/68201/

Azizan, M. A., Kariya, M. A., \& Jasmi, K. A. (2019). Media sosial dan penyebaran budaya transeksual menurut Islam. Paper Presented at the Science and Technology Science Seminar, Johor, Malaysia. Retrieved from

http://eprints.utm.my/id/eprint/85128/1/19\%20ArifAzizi_MediaSosial\%26Transeksual dalamPandanganIslam.297-312.pdf

Azmi, M., Kamalanathan, S., \& Jimaain, S. (2019). Media Sosial dan Generasi Muda Menurut Islam. Paper Presented at the Science and Technology Science Seminar, Johor, Malaysia. Retrieved from http://eprints.utm.my/id/eprint/85049/1/6\%20MohamadRafiuddinMohdAzmi2019_ MediaSosialdanGenerasiMuda.87-100.pdf

Bernama. (2020). Kronologi PKP Setakat 10 April. Retrieved from https://www.google.com.my/amp/s/www.hmetro.com.my/node/564864/amp

Fauzi, N. (2017). Penggunaan media sosial dalam dunia tanpa sempadan: Suatu kebaikan atau keburukan.

Retrieved from http://www.ilkap.gov.my/download/kertaspenyelidikan/PMSDDTS18122017.pdf

Idris, R., Ibrahim, M. I., \& Arifin, L. (2020). COVID-19: PKP dilanjutkan hingga 28 April. Retrieved from https://www.bharian.com.my/berita/nasional/2020/04/675471/covid19-pkp-dilanjutkan-hingga-28-april

Jasmi, K. A. (2012). Metodologi Pengumpulan Data dalam Penyelidikan [Paper Presentation]. Kursus Penyelidikan Kualitatif, Institut Pendidikan Guru Malaysia Kampus Temenggong Ibrahim, Johor Bharu.

Mohamed, M. A. (2011). Penggunaan sistem e-learning di Fakulti Pendidikan Universiti Teknologi Malaysia (Bachelor's thesis, Universiti Teknologi Malaysia). Retrieved from http://www.fp.utm.my/epusatsumber/pdffail/ptkghdfwP/AZIZOLAP050105TTP.pdf

Moktar, N. A., Sherryna, A. H., \& Jasmi, K. A. (2019). Media Sosial dan Kaedah Pengajaran Menurut Islam. Paper presented at the Seminar Sains Teknologi dan Manusia, Johor, Malaysia. Retrieved from http://eprints.utm.my/id/eprint/85123/1/14\%20NoorAthirahMoktar2020_MediaSosia IdanKaedahPengajaranMenurutlslam.211-226.pdf

Mutalib, M. A., Abd Halim, N. D., \& Yahaya, N. (2015). A Review on Use of Social Media In Teaching and Learning. Paper presented at the 2nd International Education Postgraduate Seminar (IEPS), Johor Bahru, Malaysia. Retrieved from 
http://eprints.utm.my/id/eprint/61182/1/NoorDayanaAbd2015_AReviewonUseofSoci alMediainTeaching.pdf

Mutalib, Z. A. (2020). FOMCA minta hentikan pembelian panik. Retrieved from https://www.bharian.com.my/berita/nasional/2020/03/666135/fomca-mintahentikan-pembelian-panik

Norazman, H., Kumar, K., \& Basiron, B. (2019). Media sosial dan perpustakaan menurut Islam. Paper presented at the Seminar Sains Teknologi dan Manusia. Universiti Teknologi Malaysia, Malaysia. Retrieved from http://eprints.utm.my/id/eprint/85125/1/16\%20Hasan\%20Norazman2019_\%20Media SosialdanPerpustakaanMenurutlslam.241-256.pdf

Roslan, S., \& Aling, Y. D. (2020). Pergerakan lebih $10 \mathrm{~km}$ dibenarkan. Retrieved from https://www.hmetro.com.my/utama/2020/04/572607/pergerakan-lebih-10-kmdibenarkan-metrotv

Sharudin, S. A., Mustaffa, N., \& Sannusi, S. N. (2020). PERANAN VISUAL INSTAGRAM DALAM MENINGKATKAN KESEDARAN KESIHATAN MASYARAKAT. e-Bangi : Journal of Social Sciences and Humanities, 17(2), 91-103.

Zakaria, Z. A., \& Abdullah, N. (2018). Learners' perceptions on the use of Whatsapp in ESL classroom. Journal Of Education And Social Science, 4(6), 96-104.

Zulkifli, Z. I. (2017). Bentuk Dan Fungsi Penukaran Kod Antara Bahasa Melayu Dengan Bahasa Inggeris Dalam Media Sosial Twitter (Unpublished doctoral dissertation). Universiti Sains Malaysia. 